\title{
Geological map of Denmark 1:50 000 - map sheet Mors, NW Denmark
}

\author{
Stig A. Schack Pedersen, Peter Roll Jakobsen, Lisbeth Tougaard and Peter Gravesen
}

Danish geological maps of deposits occurring at the terrain surface are published under the name of Geological map of Denmark 1:50 000 and are based on geological field mapping at 1:25 000. Most of the published maps follow the map sheet division shown in Fig. 1. However, in some instances it is appropriate to publish geological maps covering a regional unit, such as an island. Hence, the geological map of Mors appears as the 1:50 000 map sheet Mors, which covers parts of map sheets 1116 I, 1116 II and 1116 III (Figs 1, 2; Pedersen \& Jakobsen 2012).

Mors shows spectacular examples of glaciotectonic structures that are beautifully exposed in coastal cliff sections. It also has a unique geological history, which is briefly described in this paper.

\section{Geological features of map sheet Mors}

The geological map of Mors shows deposits that are present at the terrain surface; they are mainly non-lithified Quaternary deposits. The mapping was carried out using $1 \mathrm{~m}$ long hand augers. The soil and its underlying unit were tested at c. $100 \mathrm{~m}$ intervals with the auger, which collects a sample in a groove at its tip. The auger samples are classified in the field and allotted a symbol on a 1:25000 field map. During more than 100 years of systematic mapping, about 50 symbols have been established which are used by the mapping geologist. The aim of the work is to map the boundaries between various units shown as polygons on the maps. The testing distance of $100 \mathrm{~m}$ provides a semi-statistical documentation of the recognised polygons.

Occasional outcrops of pre-Quaternary deposits are classified with letter symbols. On the geological map of Mors, the pre-Quaternary geology is presented as an inset with structural contour lines showing the elevation of the preQuaternary surface and the geological units that occur below the Quaternary deposits (Figs 2, 3). The map is mainly based on information from the Jupiter well data base, but detailed geophysical mapping of Mors (Jørgensen et al. 2005) supported the interpretation of the structural contours.

\section{The pre-Quaternary geology}

The pre-Quaternary geological features on Mors are influenced by the Erslev structure, a salt diapir in the central part of the island (Larsen \& Baumann 1982), and by glaciotectonic deformation (Gry 1940; Pedersen 2000). This is illustrated by three cross-sections documenting the relationship between the pre-Quaternary and the Quaternary geology (Fig. 2). The diameter of the circular salt diapir is $5-6 \mathrm{~km}$,

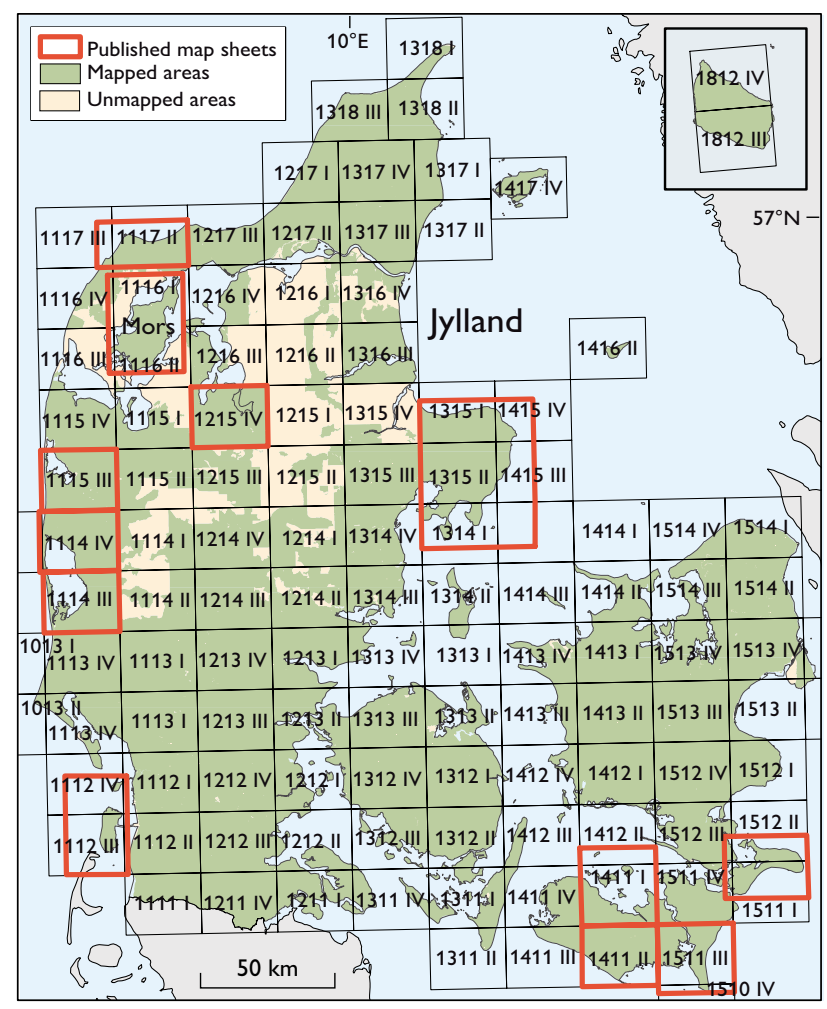

Fig. 1. Map of Denmark showing the sheet divisions of the 1:50 000 geological map series. The red frames show map sheets published under the name of Geological map of Denmark 1:50 000. The map sheets are numbered according to the 1:50 000 topographic maps implemented by the former Danish Geodetic Institute (now the Danish Geodata Agency) in 1953. The map sheet division is based on the UTM system and uses the European Datum 1950. The Survey decided to retain this map sheet division for the geological mapping, although the National Survey and Cadastre (now the Danish Geodata Agency) in 2003 started to use the European Terrestrial Reference System 1989. 


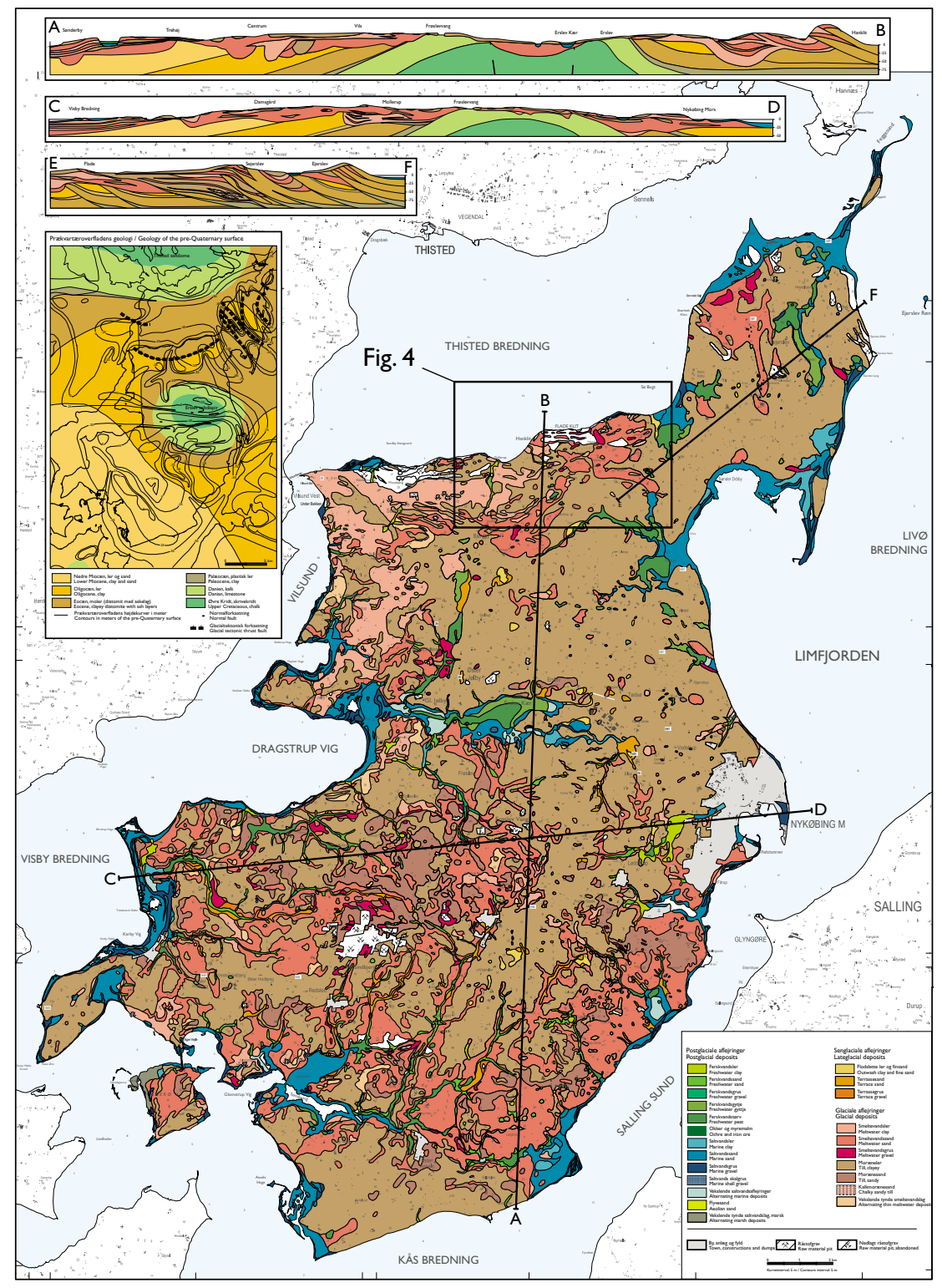

Fig. 2. Strongly reduced and modified version of map sheet Mors with three cross-sections: a $\mathrm{N}-\mathrm{S}$ section (upper), an E-W section (middle) and a NE-SW section of the northern part of Mors (lower). The inset shows the depression on central Mors which coincides with the depression in the top of the chalk covering the salt diapir (Fig. 3).

and the diapir rises vertically from the base of the Permian salt at a depth of $5-6 \mathrm{~km}$. The top of the salt in the diapir is now found at depths of $600-700 \mathrm{~m}$. A circular dome of chalk caps the salt diapir. Maastrichtian chalk in its centre was formerly quarried in chalk pits, exposing the Cretaceous-Tertiary boundary. The chalk is overlain by bryozoan cherty limestone that forms an aureole around the top of the diapir, and Paleocene clay occurs along the steeply dipping flanks. The uplift of the salt diapir continued in the Paleocene and resulted in an increased thickness of plastic clay away from the diapir centre. In the surrounding marginal depression, Eocene clayey diatomite occurs interbedded with volcanic ash layers. This unit, locally called 'moler', crops out in an old clay pit on the northern flank of the diapir (Pedersen 2000).
The moler is the most characteristic pre-Quaternary unit in the glaciotectonic complexes that occur on northern Mors. The diatomite is exploited and used for light-weight granulates. On northern Mors, glaciotectonic folds are well exposed in the two largest clay pits. These folds and the surrounding hilly terrain were formed by superimposed glaciotectonic deformation (Pedersen 2000). The most impressive glaciotectonic complex with up-thrust sheets of moler is the Hanklit complex (Figs 4, 5), where a thrust sheet is exposed that was displaced c. $300 \mathrm{~m}$ towards the foreland in the south. Parallel ridges trend from Hanklit towards the west, and also here the moler is the target of diatomite exploitation in pits following the crests of the anticlines. 


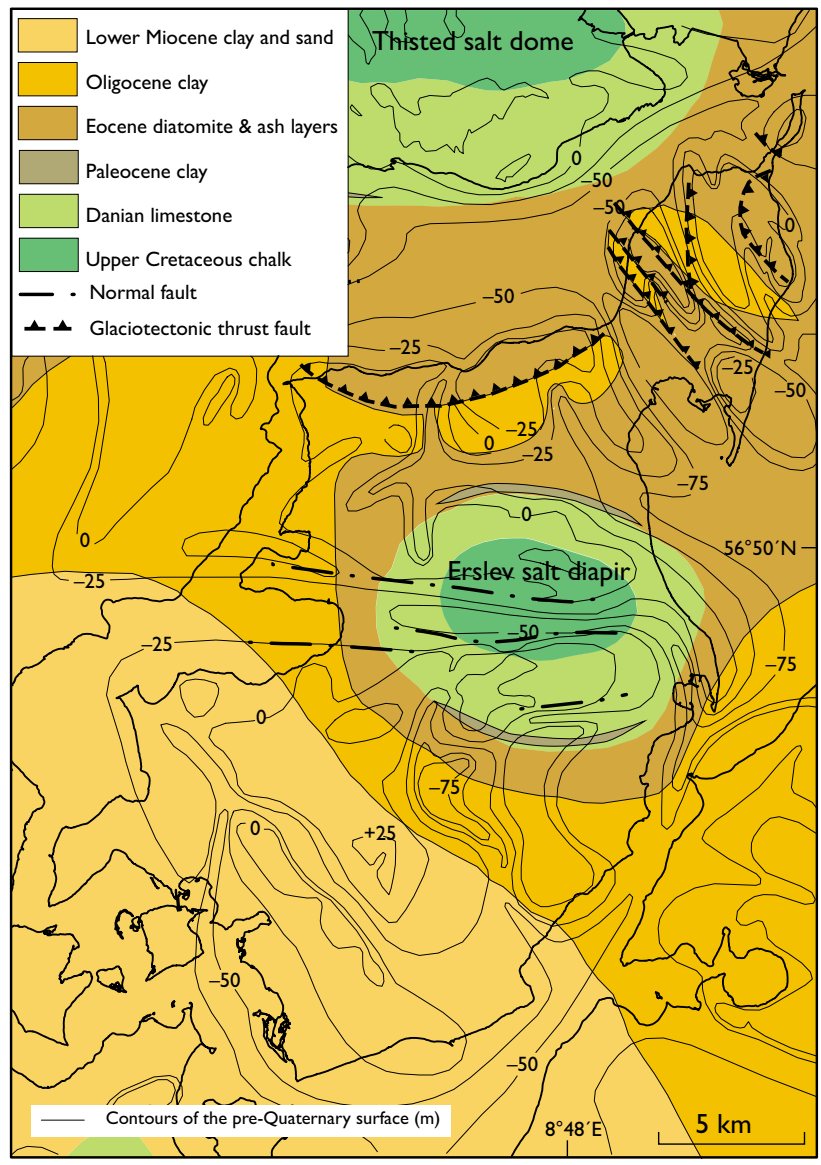

Fig. 3. Bedrock map of Mors (enlarged version of inset in Fig. 2). The structural contour lines at $25 \mathrm{~m}$ intervals show the elevation of the pre-Quaternary surface. The dome-like structure on central Mors is made of chalk that covers the top of the Erslev salt diapir. The boundaries between glaciotectonic complexes and their foreland on northern Mors are also shown.

Between the glaciotectonic complexes on northern Mors and the northern flank of the salt diapir, red and green plastic clay of the Røsnæs Ler Formation occurs together with dark brown, micaceous, Oligocene to Early Miocene clay. Local outcrops of the Oligocene-Miocene clay (the Brejning and Viborg Formations) are known in the hills along the strait west of Mors. South of the Erslev structure, Miocene heterolithic deposits with mica-rich clay and sand are known from wells and were recognised during the systematic mapping of southern Mors.

\section{The glaciodynamic geology}

The oldest Quaternary deposits on Mors comprise glaciolacustrine clay that is referred to the Elsterian Glaciation exposed in coastal cliffs on south-western Mors. On northern Mors, alternating beds of till and glaciofluvial sand are exposed along the west coast, and similar Elsterian deposits

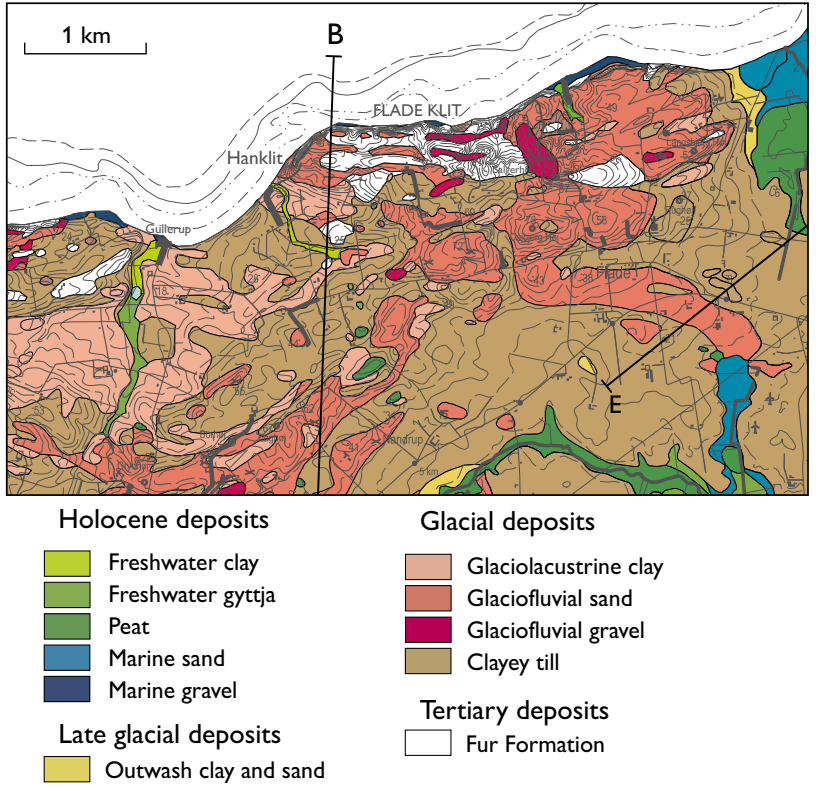

Fig. 4. Part of the map sheet showing the hilly terrain at Flade Klit. The Hanklit glaciotectonic complex is marked by a landscape dominated by elongated hills. The Fur Formation has been thrust-faulted up into parallel ridges in the complex. Farther to the south, the thrust sheets mainly consist of glaciolacustrine clay and glaciofluvial sand. Contour interval 5 m. For location see Fig. 2.

are known from wells penetrating the buried tunnel valleys. A coastal cliff along the west side of northern Mors exposes $8 \mathrm{~m}$ thick sandy till, rich in chalk, which was deposited by a Norwegian ice advance during the Saalian Glaciation (about 300000 years BP). Characteristic erratic blocks of chalk and flint, originating from erosion of the till, are abundant along the shore (Pedersen et al. 2012). This till and the underlying glaciofluvial sand and gravel are well known from diatomaceous clay pits on north-eastern Mors. Glaciolacustrine clay is widespread over large parts of northern and north-western Mors. The clay was deposited during the Middle Weichselian prior to the Norwegian Ice advance. The depocentre was located in the depression between the Thisted salt dome north of Mors and the Erslev salt diapir. Both these areas formed elevated terrains, whereas the remaining part of Mors constituted lowlands characterised by lake-filled depressions with glaciofluvial sand and gravel. In the area around Hanklit, glaciolacustrine clay forms an important element in the glaciotectonic complex (Figs 4, 5). The clay is thrust up into sheets, forming a terrain with $\mathrm{E}-\mathrm{W}$-trending parallel ridges. The arc-formed complex was created by the Norwegian Ice advance about 27000 years BP. A lodgement till rich in indicator boulders such as larvikite and rhombohedral porphyries from the Oslo region was deposited during this advance. 


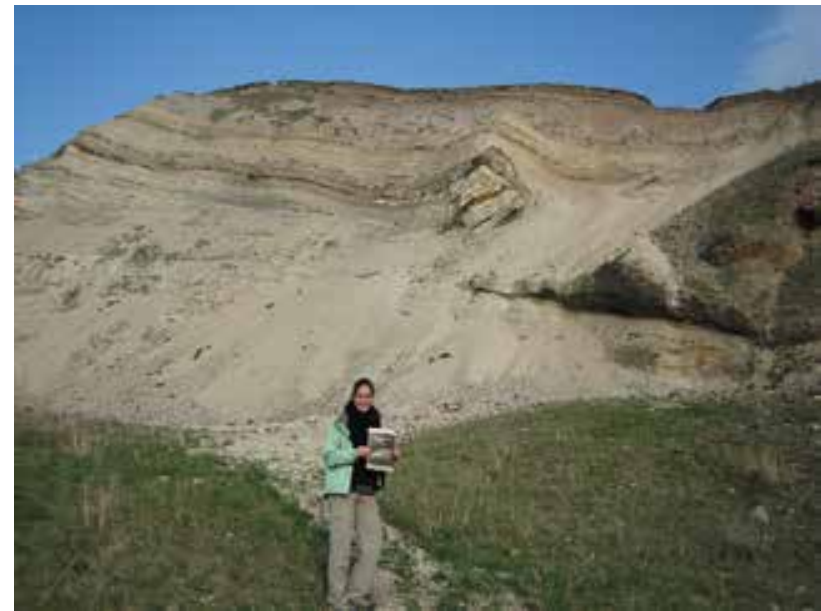

Fig. 5. The impressive glaciotectonic thrust sheet exposed in the Hanklit coastal cliff. The thrust sheet is $60 \mathrm{~m}$ thick and was displaced for a distance of $300 \mathrm{~m}$ towards the foreland to the south.

After the Norwegian Ice melted back, Mors was characterised by parallel hills intersected by lake-filled valleys with glaciolacustrine clay deposits as patches scattered over the landscape. A few thousand years later the advancing Swedish Ice remodelled the landscape. On northern Mors, thrusting and folding from the north-east superimposed the architecture of the glaciomorphological landscape. When the ice reached south-western Mors it stopped briefly and formed a stationary line, and its meltwater created a cone-shaped outwash plain. At its apex, boulders, stones and gravel were deposited, which are now quarried in gravel pits.

\section{The postglacial geology}

During the late glacial and Holocene periods, Mors was affected by three significant events: (1) meltwater erosion during the deglaciation and formation of a kettle-hole landscape caused by melting of dead ice, (2) marine transgression ac- companied by sedimentation in straits and fjords after the Ice Age, and (3) glacio-isostatic rebound. During the Atlantic sea-level highstand, coastal plains formed in front of the fossil coastal cliffs.

A number of fossil straits and fjords with marine gyttja and marine sand occur on Mors. The most significant fossil fjord is an E-W-trending depression located above the central part of the salt diapir on central Mors. Marine heterolithic deposits are characterised by shells of Cardium, and mounds of oyster (Ostrea edulis) beds formed where strong currents cut narrow gaps in the former fjord. A number of distinctive fossil coastal cliffs occur, particularly on northern Mors where raised shorelines are found up to $c .5 \mathrm{~m}$ above the present sea level. The raised beaches have occasionally dammed coastal lakes. Beach ridges occur along the coastline on southern Mors. Several of these contribute to the closure of small fjords and coastal lakes with peat accumulation. In the past, the coastal plains were larger, but are now subjected to increased erosion along the coastline of Mors.

\section{References}

Gry, H. 1940: De istektoniske Forhold i Moleret. Med Bemærkninger om vore dislocerede Klinters Dannelse og om den negative Askeserie. Meddelelser fra Dansk Geologisk Forening 9, 586-627.

Jørgensen, F., Sandersen, P.B.E., Auken, E., Lykke-Andersen, H. \& Sørensen, K. 2005: Contributions to the geological mapping of Mors, Denmark - a study based on a large-scale TEM survey. Bulletin of the Geological Society of Denmark 52, 53-75.

Larsen, G. \& Baumann, J. 1982: Træk af Mors salthorstens udvikling. Dansk Geologisk Forening, Årsskrift for 1981, 151-155.

Pedersen, G.K et al. 2012: Molerområdets geologi - sedimenter, fossiler, askelag og glacialtektonik. Geologisk Tidsskrift 2011, 41-135.

Pedersen, S.A.S. 2000: Superimposed deformation in glaciotectonics. Bulletin of the Geological Society of Denmark 46, 125-144.

Pedersen, S.A.S. \& Jakobsen, P.R. 2012: Geological map of Denmark, 1:50 000, Mors. Copenhagen: Geological Survey of Denmark and Greenland.

\footnotetext{
Authors' address

Geological Survey of Denmark and Greenland, Øster Voldgade 10, DK-1350 Copenhagen K, Denmark. E-mail: sasp@geus.dk
} 